\title{
Economic Development in Afghanistan
}

\author{
Rahmanullah Rasa
}

\begin{abstract}
This study examined the economic development in Afghanistan in 2002-2019. Secondary data were used, which were collected and retrieved from annual reports of various public, non-government's organizations and World Bank. Using descriptive statistics analysis, it was found that the overall economic situations and performances of the country aren't in accordance with the expectations, poverty and unemployment rates are constantly increasing. Afghanistan had huge trade deficit in the study period, on average imports raised by 88.33 percent from US \$3251 million in 2002 to US \$7407 million in 2018. Furthermore, economic growth declined from 8.8 percent in 2003 to 1.0 percent in 2018. Real GDP per capita was only US \$ 520.9 in 2018. Reduction in international aids, withdrawal of international forces, worsening security situations, political instability, high corruption, severe droughts, higher population growth rate than economic growth rate, weak investors' confidence and lack of smooth political transition are the main reasons that have had adverse effects on Afghanistan's economic growth.
\end{abstract}

Keywords: Economic development, economic growth, GDP, imports \& exports, Afghanistan

\section{INTRODUCTION}

F orty years of war and conflict had destroyed almost every infrastructure and institution in Afghanistan. Major sectors of the economy such as industry, agriculture and service had been mostly damaged during the wartime. In addition, majority of the countrymen were living below the poverty line. Financial and banking systems stopped functioning during the Taliban regime. International community had paid great attention to the reconstruction of fundamentals sectors in Afghanistan soon after 9/11 and the collapse of Taliban regime in the country. Establishing new constitution, liberalization of financial system and banking sector in 2002 encouraged and prompted all sectors in the country. The new constitution have laid the foundation for the market-based economy and allowed the government to replace closed and centralized economy on open and market-based economic system. According to the market-based economic system, the government plays a role as a regulator not a producer of goods with a clear separation between the public and private sectors. International community has been supporting public and private sectors' development and economic growth in the country since 2001. However, no significant efforts have been made to either reinstate the past economic structure, or develop new ones

Revised Manuscript Received on October 10, 2020.

* Correspondence Author

Rahmanullah Rasa*, PhD candidate at Shanghai University, Faculty at Shaikh Zayed University, Khost, Afghanistan. Email: Rahmanullah.rasa@szu.edu.af

(C) The Authors. Published by Blue Eyes Intelligence Engineering and Sciences Publication (BEIESP). This is an open access article under the CC BY-NC-ND license (http://creativecommons.org/licenses/by-nc-nd/4.0/) that could help to build a modern state and developed economy. Instead, energy was wasted on projects and activities in the name of privatization and the free market, which have brought more harm than benefit to the country and economy[37]. Furthermore, security and political instability severely harmed the economic development and have continually decreased investment and rapidity of economic development processes in Afghanistan. The collapse of Kabul Bank- the largest commercial bank in Afghanistan- in 2010 as a result of fraud, corruption and political instability imposed significant fiscal cost on the economy. The embezzlement of the bank was \$987.7 million, which threatened the whole banking sector very badly and the trustworthiness of Afghans on banking sector gradually decreased[43]. Afghanistan economy has seen lots of ups and downs in the last two decades. The prolong war has severely depressed the economic activities until 2001. After the collapse of Taliban regime, when the recovery began, the economy rebounded strongly posting real Gross Domestic Products (GDP) growth rates of 8.8 percent in 2003 and 1.4 percent in 2004. Despite of a severe drought, which adversely effect on agriculture reduction, the overall real GDP growth rate was maintained at an impressive level of 11.2 percent in 2005. The economy lost momentum in 2006 with growth declining to 5.8 percent from 11.2 percent in 2005[12]. Insecurity has slowed down economic growth of the country in different periods. With the withdrawal of international security forces starting in 2011 and with the subsequent security and political transition in 2014, Afghanistan's growth trajectory has declined significantly. Mean growth plummeted from an average annual rate of 9.4 percent in the period from 2003 to 2012 to 2.1 percent in the period from 2013 to 2016. In 2016, the growth rate increased to 2.2 percent,from 1.1 percentin 2015, principally due to the strong growth of the agriculture sector. The significant decline in growth since 2012 reflects the impact of reduced aid and weak investor's confidence because of the increasing insecurity and continued political uncertainty[10]. After the political transition in 2014, the annual growth rate has slightly declined for the coming years. The annual growth rate in 2017 was 2.7 percent and 1.0 percent in 2018, the slowest since 2001[4]. However, it was forecasted 2.7 percent in 2019 and 3.4 percent in 2020[2]. International assistance and aid are the main drivers of this growth, which dropped from \$ 6.5 billion in 2010 to $\$ 4.3$ billion in 2015 and has continued to fall since then. There were two major reasons for the economic downturn of 2018. First, in late 2017 and early 2018, Afghanistan experienced the worst drought in decades, which has caused a sharp decline in agricultural and livestock productivity. Second, the business environment and investors' confidence deteriorated due to intensifying violence and ongoing political uncertainty.

DOI:10.35940/ijmh.B1153.105220

Journal Website: www.ijmh.org
Published By:

Blue Eyes Intelligence Engineering

\& Sciences Publication

(C) Copyright: All rights reserved.

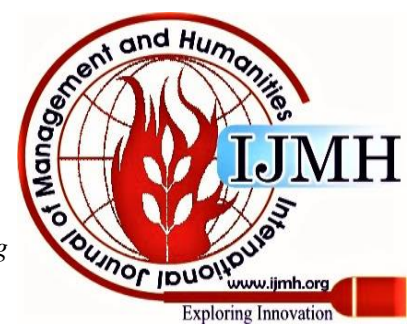




\section{Economic Development in Afghanistan}

Furthermore, the poverty has grown deeper and more widespread due to drought conditions, internal displacement, and low economic growth.

The bulk of the poor population lives in drought-affected rural areas, leading to a large increase in the number of displacement, which has reached a record level of 298,000 individuals. Roughly $54 \%$ of the population now lives below the national poverty line, compare to $38.3 \%$ in 2011-12[4]. Afghan government have paid great attention to agriculture sector in the last decade. Considerable amounts have been invested in irrigation canals, livestock and agricultural farms, greenhouses and other subsector in the agriculture sector. Noticeably wheat is one of the important agricultural crops and the main source of nutrition for the people of the country. That is why wheat is widely grown by famers throughout Afghanistan. Wheat cultivation and production, especially in rainfed areas, is directly dependent upon adequate and timely precipitation. According to National Statistics and Information Authority (NISA), the agriculture (irrigated and rainfall) and wheat cultivation area has increased and the total wheat production for the country is estimated above 5.1 million metric tons in 2019 showing 1.52 million metric tons increase compared to last year. This is the highest production point for the country in the last 13 years.After the fall of Taliban regime, Afghan government and international community had paid great attention to promote private sector in the country. Service sector was fairly encourage to invest significant amounts in its subsectors. Banking, telecommunication and education were the main leading subsectors in which considerable investments have been done. Communications have rapidly expanded after the fall of Taliban regime in late 2001. Six telecom companies operate in the country now. Furthermore, banking sector has also been hurriedly expanded and significant investments have been made in the sector. There are fourteen commercial banks consisting of eight private, three state-owned and three foreign commercial banks. Due to lack of enough financial markets and capacity, the financial sector is mostly controlled by commercial banks. Moreover, education sector is another substantial subsector in which significant progress has been made in last two decades. Private sector has been made significant investments both in education and higher education. The education sector is witness of dramatic growth in recent years and thousands of private primary, secondary and high schools and hundreds of institutes and universities have been established. Likewise the other sectors of the economy, industry sector of the country had been mostly destroyed by the forty prolonged war and conflict in the country. After the formation of new government in 2001, both public and private sectors have invested significant amounts in the sector, significant small and medium size enterprises, factories and other manufacturing units have been established. To promote and facilitate the sector, the government has established industrial parks in five different zones in the country. The sector is still in the preliminary stage, and hasn't been well developed. However, private sector has invested in the sector and produce varieties products such as marble, soap, mineral water, laundry Soda, shoes, beverages, textile, carpet, cement, fertilizer, copper, plastic, cloths, leather goods, statues, plastic pipelines, talc, salt, stones and many other basic products.

Afghanistan is a wealthy country by nature. It has huge deposits of natural and nonfuel mineral reserves, which include both known and potential deposits of different types of minerals such as iron, copper, lithium, bauxite, silver, and rare earth metals among others and the total value of minerals could be worth more than $\$ 3$ trillion, which are sufficient to fundamentally change the economy of the country[48]. Due to war and conflict, corruption, weak infrastructure, fragile government, weak industry and other sectors, Afghanistan is a consumption country for a long time and has negative trade balance for the last twenty years. However, Afghan government has been making great efforts to become an exporting country. The government made export-oriented polices to increase exports and decrease imports accordingly. According to the Ministry of Commerce and Industry (MoCI) Afghanistan exports have increased dramatically over the past five years from \$ 556 million in 2015 to \$864 million in 2018. Similarly, the country's imports have been decreased from \$7679 million in 2015 to \$7407 million in 2018.

\section{LITERATURE REVIEW}

Growth in agriculture sector is an extremely important for encouraging and boosting economic development and feeding rising populations in most developing countries in the world[45]. However, as the expansion of area and irrigation have become the lowest sources of output growth in the world, agricultural growth depends more on technological growth to increase production[31]. New agricultural technologies and improved practices perform important roles in increasing agricultural yields in developing countries. In the case of success, the use of improved agricultural technologies can promote overall economic growth through intersectoral linkages while protecting natural resources[23],[46]. The relationship between poverty, food insecurity, agriculture and environmental destruction and the impact of farming practices are important issues in the last few decades and received substantial consideration. To increase productivity in the agriculture sector, new techniques have been introduced in many countries.Agricultural sector has been significant for prompting growth and to overcome poverty and increase food security in much of sub-Saharan Africa. Though, agriculture is often characterized by low use of modern technology and low productivity[7].Improving the productivity, profitability and sustainability of smallholder farming and agriculture are the main ways to get rid of poverty in the region[8]. Likewise, in an area where agriculture is the main sector supporting the livelihoods of most of the poor, more and more new agricultural practices are being adopted, and technologies such as high-yielding species and related products (such as crop insurance) are likely to contribute to the economic growth and poverty reduction among the poor[33]. Researchers[25]point out that technology is an important source of agricultural productivity growth, which can lead to higher income and lower poverty. This was observed during the Green Revolution of the 1960s and 1970s, especially in Asia and parts of South and Central America. Another study[24]found that the adoption of improved agricultural techniques (improved varieties and agronomic methods) had a positive and significant impact on food security in Ethiopian households. 
Furthermore,[36]studied the impact of the adoption of agricultural technologies on poverty reduction in rural Bangladesh and found a strong and positive impact on farmers' welfare. Another research[49]conducted an impact study in rural areas of China and found that the adoption of agricultural technologies had a positive impact on farmers' well-being, thereby increasing household income. For a long time, companies and firms have been considered as one of the determinants of economic growth and the factors that affecting their performance have attracted many researchers. Among them, Robert Gibrat's work is considered the first formal model dealing with the dynamics of firm size and industry structure[47]. According to[39]investigation the main obstacles of doing business in Cameroon using 2009 ES data from retail companies in 2009. His findings indicate that taxes, illegal trade, lack of infrastructure, lack of credit channels, administrative delays and incompetent labor were the main obstacles for Cameroonian retail companies. The authors showed that factors related to the business environment have greatly reduced the annual gross profit margin of domestic traders. Based on[27]study the prevalence and determinants of high-growth businesses in 11 sub-Saharan African countries and found that among all the countries surveyed, electricity and access to finance were the major constraints among the listed elements of a business environment. In addition, [28]conducted a comprehensive study of the role of sub-Saharan Africa with respect to the business environment of other developing countries using ES data from the World Bank in 2001.They found that employment growth in the region was relatively concentrated in the smallest firms and companies. Their findings showed that medium and large firms and companies grew less rapidly as compared to other parts of the world. The main reasons could be that firms in Africa faced greater challenges in accessing finance, reliable infrastructure services and other public services deemed crucial for growth which may have hindered the growth of large firms relative to small firms. The main objective of macroeconomic policies in many countries is that to reduce poverty, stable economic growth and lower inflation and unemployment. In developing countries, supply side shocks, fiscal deficit, government expenditure and interest rate are those internal aspects which are statistically significant determinants of inflation[15]. Usually, fiscal policy has been linked with the use of taxation and public expenditure to affect the level of economic activities[50].Fiscal policy involves deliberate government action on expenditures and taxes, with the goal of affecting macroeconomic variables in the desired direction, including sustainable economic growth, creating high employment opportunities and lower inflation[22],[1]. Researchers[6]conducted an empirical study on the impact of fiscal policy on Pakistan's economic growth. They used the ARDL method and found that the increasing fiscal deficit createdexcessive demand, which stimulated companies to make more use of existing capabilities and people to spend more money and increase the economic situation improved in the short run. In the long run the rising fiscal deficit had a negative effect on economic growth. The relationship between US government size and economic growth using time series data from 1950 to 2007 was investigated[12]. The results showed that an increasegovernment consumption slowed economic growth, while an increase government investments promoted and increased economic growth. Moreover, [5]measured the impact of Jordanian government expenditure on economic growth from 1980 to 2013, and the results showed that both total government expenditure and current government expenditure had a positive impact on economic growth. The relationship between public expenditure on education and economic growth in China was studied[32]. His empirical findings show that there was a positive and significant relationship between public expenditure, education and economic growth. In addition,[14]studied the growth effect of government spending in a group of 30 developing countries in the 1970 s and 1980s, with special attention to disaggregated government spending. They found that total government investments and education spending were the only expenditures significantly associated with growth. The impact of various components of government expenditure such as investment, consumption, and human capital on economic growth was investigated by[34], the study found that only human capital, education and health) had a long-term impact on economic growth. Age and performance of a firm and company are a critical issue that have to be considered. Some theories suggest a positive relationship between the twos. However, others indicate and discuss that the reverse relationship is true. Researcher[30]studied the sources of labor productivity and its evolution in China from 2000-2009 across provinces. They estimated determinants of labor productivity in China using the fixed-effects panel data model with time and province-specific affects and robust standard errors where labor productivity was measured both in level and in growth rates. They found that labor productivity was positively correlated with industry output, investments in fixed assets and telecommunications, total volume of the business post-profits of the enterprises and the average wage for labor both in level and growth rates. Furthermore,[29]used the World Bank's 2013 Enterprise Survey Database to analyze labor productivity and its determinants in Kenya's manufacturing and service industries. Using OLS with robust standard errors, they show that capital intensity and wage are significant and positively affected labor productivity, and that a higher proportion of women in the labor force reduces labor productivity. It has been found that training and education of workers have a positive impact on labor productivity. The relationship between firm age and performance, using firms from Sweden during 1997-2010 was studied by[16]. The study found that sales growth for new firms was characterized by positive autocorrelation while it showed a negative autocorrelation for older firms. Besides that,[3]investigated the effect of a firm's age on its productivity using Turkish firms from 2005-2014. The study used a fixed-effects model with robust standard errors. They used a variety of profitability measures such as return on assets and return on equity and the findings indicated that there was negative and convex relationship between a firm's age and profitability which indicates that firms is facing profitability decline over time. 


\section{Economic Development in Afghanistan}

In addition, another study[43]was conducted on the relationship between productivity, size and age of large Australian firms employing more than 100 employees and used the World Bank database on large manufacturing firms in Australia. The study found that there was an inverse relationship between company productivity and age and on average the larger and older companies were less productive.

\section{RESULT AND DISCUSSION}

The total population of Afghanistan was estimated to be about 32.3 million in 2019. Around 16.4 million are males and 15.8 million are females. Majority of the population, 23 million ( $71.4 \%$ ) live in rural areas, 7.7 million (23.9\%) live in urban areas and the rest 1.5 million (4.7\%) are nomads[41]. Afghanistan economy has been traditionally dominated and its growth has been contributed for a large part by agriculture. Around 70 percent of the population live and work in rural areas; mainly work on farms and agriculture sector, and 61 percent of all households derive income from agriculture. Despite a decline in its share in the overall economy, the sector still employs 40 percent of the total workforce. With the right mix of policies and investments, the agriculture sector can reduce poverty and boost sustainable growth in Afghanistan through jobs, better productivity, and inclusiveness[13].

According to the data of Ministry of Agriculture, Irrigation and Livestock (MAIL), the Afghan government has completely reconstructed and created 648 irrigation networks and canals in the country during 2015-2018, and 21 irrigation networks were in progress. Furthermore, 1,258 water reservoirs with a capacity of 500 cubic meters of water were created. In the mentioned period, MAIL has distributed 160 pedal pumps and drilled 329 deep wells with the installation of a Solar pump for irrigation. Besides that, 50 small control dams and 79 small watershed and 106 water storages have been constructed in 32 provinces[21].

Horticulture is an important subsector in Afghanistan, to enhance sustainable production of the sector, including development of valuable products such as apples, grapes, pomegranates, apricots, plums, pistachios, raisins and almonds, and improvement of rural livelihoods in the community and market, 57,436.5 acres of new gardens have been established and 7,000 acres of old-fashioned gardens has been reconstructed. Furthermore, 3,076.5 acres of dense and semi-dense gardens with the installation of a grape vining system have been constructed, while 47,491 acres of local garden areas were restored, 14,486.5 acres of pistachio gardens have been created in dry areas by the government during 2015-2018. Besides that, the government has constructed 4,467 large and small greenhouses and raisin storages. Furthermore, for raising saffron cultivation level, over 13,013 acres of land have been cultivated saffron and 302.5 metric tons of saffron corms have been purchased and distributed. The saffron production level reached 16 metric tons in 2018[35].

Wheat is one of the most important agricultural corps and the main source of nutrition for the people of Afghanistan that is why it is widely grown by farmers in the country. The cultivation and production of wheat are directly dependent upon adequate and timely irrigation and precipitation. The figure 1 below shows wheat production and precipitation in Afghanistan.

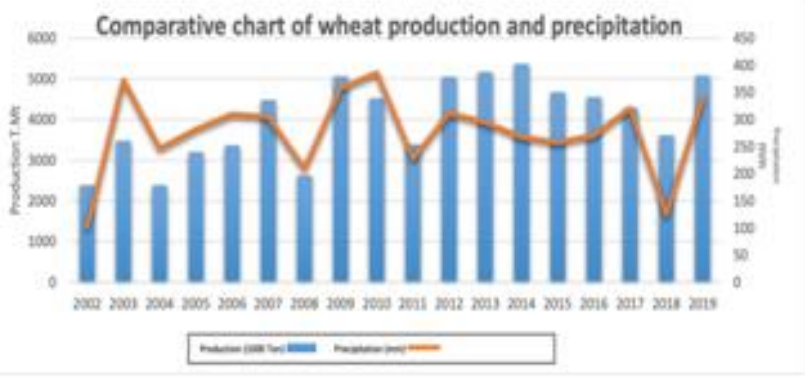

Fig.1. Comparative chart of wheat production and precipitation [35]

Severe droughts in different periods have had negative impact on wheat production in Afghanistan in the last 19 years. The country has experienced wheat deficit in the last two decades. In 2018 the wheat deficit was 2.3 million metric tons. Based on the population estimates in 2019, wheat demand for the year2019was calculated to be around 6 million metric tons, while wheat deficit of the country was expected to be around 1 million metric tons[40]. Agriculture sector has not been well developed in Afghanistan. Due to overall situation and government weak agricultural monitors and polices, agricultural productivity growth couldn't lead to higher income and lower poverty in the country. In the last two decades, agricultural technologies and improved practices haven't been in place to play an important role to increase agricultural yields in the country. Adoption of new agricultural practices and using new technologies in the sector are expected to contribute to the economic growth and poverty reduction correspondingly, but it hasn't been fully implemented in Afghanistan yet. Near constant rose in rural poverty rates which was 55 percent of the population and food insecurity rates rose to 45 percent in 2016/17, clearly showed that Afghanistan's agricultural policy has been failed to achieve its goals. The country simply does not have the right conditions to promote strong agricultural growth. As a result, "business as usual" economic methods and models that may work elsewhere may not work in Afghanistan. To protect and stimulate domestic production, government imposing broad-based import duties on agricultural cash crops and products. The structure and regulation of Afghanistan's rural economy is more through social relations than market relations. The country needs a more politically informed and environment-centered approach to economic development[42]. Banking sector has been expanded significantly in the last 18 years. The first private bank was established in 2003 and the number of banks have been increased to fourteen in 2019. The sector is consisted of three state owned banks, seven private commercial banks, one private Islamic bank, and three branches of foreign commercial banks.

According to [17],[18],[19],[20] and[21]annual reports, deposits are the main funding source in the Afghan banking sector including interbank and customer deposits. The assets size of the banking sector raised from AFN 64.2 billion in 2006 to AFN 316.34 in 2019, which indicate significant growth in total assets of the sector that makes 20.82 percent of total GDP.

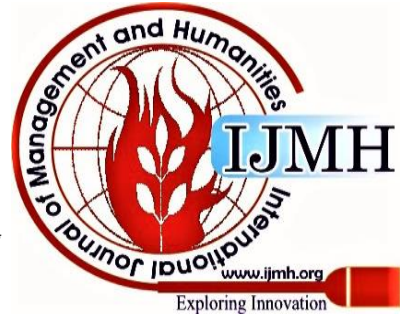


The banking sector total loans are designated in Kabul and other major cities to trade, service, construction, infrastructure, real estate, telecommunications, farms, and livestock and agriculture sectors. Increase in operating expenses and taxes, decrease in non-interest and interest income, insecurity, political instability, and slow economic growth in the recent years have negative impact on overall performance, especially return on profitability of the banking sector. In addition, poor governance of credit risk has increased non-performance loans and had negative impact over the profitability and capital adequacy of the banks during 10 years. Credit risk was one of the main reasons of Kabul Bank collapse in 2010 which hadthreatened the whole banking system in Afghanistan[44].

Industry and manufacturing sector is the main source of economic development of a country. Significant investments in the sector stimulate development and enhance economic growth. Although billions US dollar of international aids pumped to Afghanistan's economy with the formation of new government in 2001, manufacturing sector hasn't been promoted and developed significantly. Afghanistan has rich sources of industrial products in the region if it is managed and utilized professionally, and will play fundamental role in economic development. Weak and insufficient production's capacity, insecurity, lack of access to new technology and finance, lack of innovation, electricity, inappropriate environment for investment, and lack of skilled workforce are the main barriers in the industry and manufacturing sector in Afghanistan.

According to the world bank annual development update reports of Afghanistan, the average share of industry and manufacturing sector was 24.3 percent of total GDP during 2015-2019. In the aforementioned period, the average growth rate of the sector was 1.54 percent per year, which is not satisfactory and needs significant improvement.

According to the World Bank, with the beginning of the withdrawal of international security forces in 2012, followed by the security and political transition in 2014, economic growth in Afghanistan has declined significantly.

Afghanistan has experienced erratic GDP annual growth rate during 2002-2018. In 2003 the growth rate was 8.8 percent and declined to 1.4 percent in 2004. International assistance and significant investments in private sector increased the economic growth to 11.2 percent in 2005.

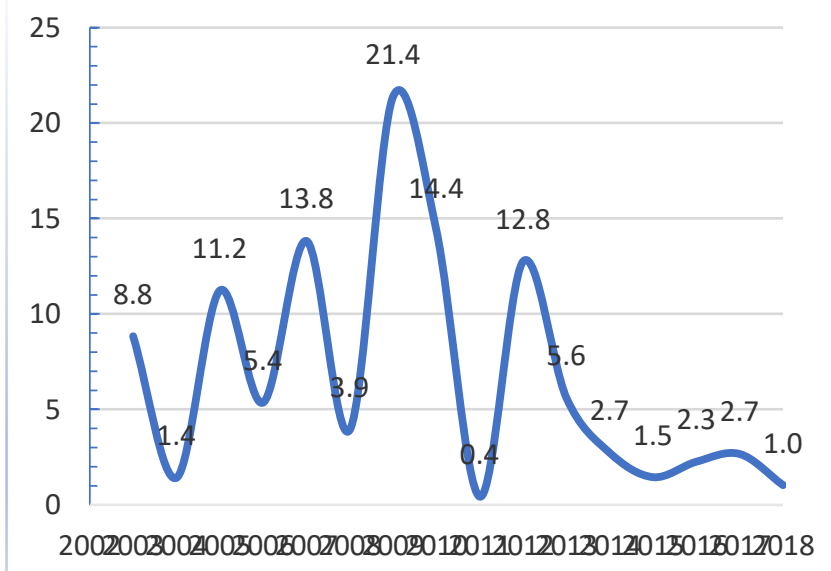

Fig.2. GDP growth (Annual \%)
Severe drought badly damaged agriculture sector in 2006, consequently the growth was declined to 5.4 percent. The average annual growth rate in the last 16 years was 6.8 percent. There was a weak recover in 2016, with the rate increasing from 1.1 percent in 2015 to 2.3 percent in 2016, primarily due to the strong growth of the agriculture sector in that year and increased investment and business confidence compared to 2015. Reduction in aid ( from US \$12.5 billion in 2009 to around US $\$ 8.8$ billion in 2015) , low levels of investors' confidence, and continued political uncertainty in the challenging security environment were the main reasons due to which economic growth has been declined significantly since 2012 .
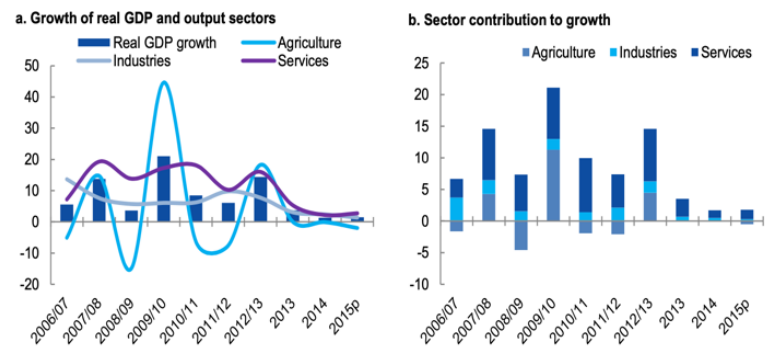

Fig.3.Sector contribution to growth[9]
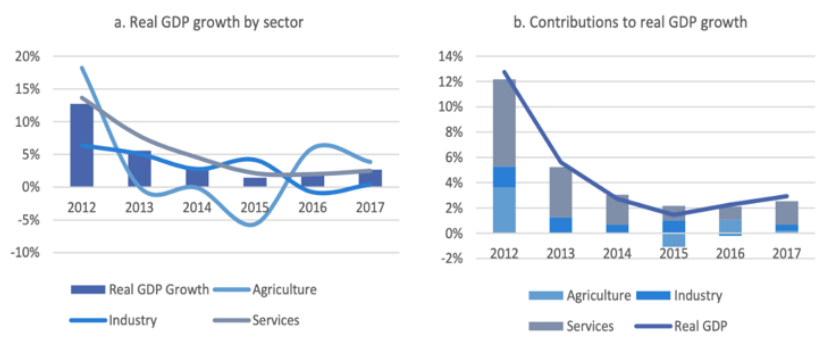

Fig.4. Real GDP by sector[11]

Based on[10]development update, estimated population growth rate 3 percent per year, worse security situation and slow moving of GDP growth have caused to increase poverty in Afghanistan. According to NISA data, the poverty increased from 35.8 percent in 2011-12 to 39.1 percent in 2013-14. According to World Bank, a few large-scale investment projects were launched in 2015 and foreign direct investment remained very low. Furthermore, Turkmenistan-Afghanistan-Pakistan-India (TAPI) pipeline, Central Asia South Asia (CASA)-1000 electricity and Trans-Hindukush road connectivity are the largest and most visible public infrastructure projects, which are currently under preparation. Due to Opening of Chabahar port, improvement in investment confidence in service sector and improved perceptions of the security situation, the economy was recovered slightly and grew by 2.7 percent in 2017. The economic growth was declined from 2.7 percent in 2017 to 1.0 percent in 2018. In 2018 overall new business license applications, service and manufacturing sector registrations were declined by about 20 percent.

Exports and imports of goods and services of Afghanistan in figure 4 and 5 represent the value of all goods and other market services provided to and received from the rest of the world.

Published By:

Blue Eyes Intelligence Engineering

\& Sciences Publication

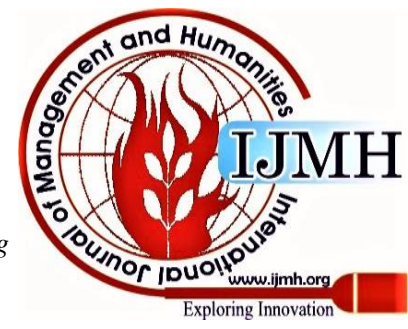




\section{Economic Development in Afghanistan}

They include the value of merchandise, freight, insurance, transport, travel, royalties, license fees, and other services, such as communication, construction, financial, information, business, personal, and government services. They exclude compensation of employees and investment income (formerly called factor services) and transfer payments.

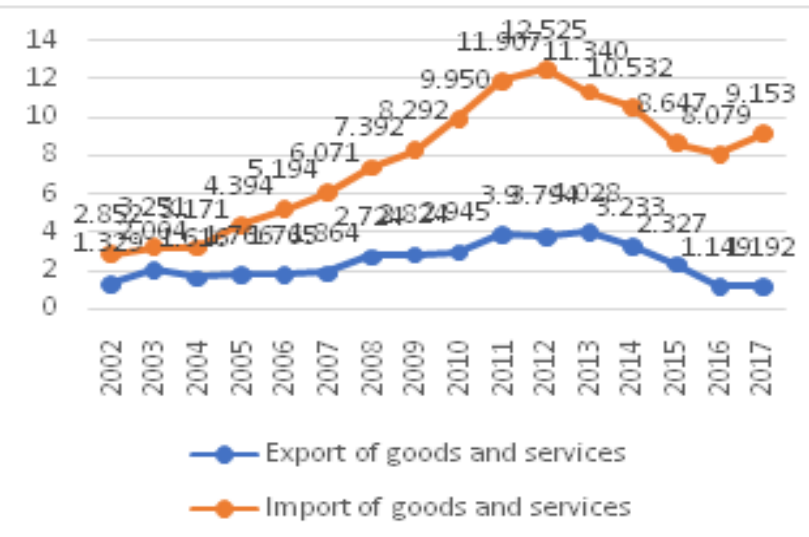

Fig.5. Imports and Exports of goods and services in billion US \$

The imports of goods and services in 2002 were US \$2.852 billion and continuously increased and reached to the peak of US $\$ 12.525$ billion in 2013. There has been significant difference between imports of goods and services, and exports of goods and services during 2002-2017. Exports of goods and services were US $\$ 1.329$ billion in 2002, reached to the peak of US $\$ 4.028$ billion in 2013. Withdrawal of international forces, reduction in aid, worsening security situation, investors' confidence deterioration and political uncertainty were the main reasons to dramatically declined exports of goods and services to US \$1.192 billion in 2017. Afghanistan is an importing country for a long time and has had negative trade balance during the last two decades. The main import partners of Afghanistan are: Pakistan, Iran, India, Russia, China, Common wealth and United States, while export partners are: Pakistan, India, Iran and China. Afghanistan has been struggling to become an exporting country. To reach and accomplish this goal, the government has made efforts and export-oriented policies to promote exports in the country. According to the Ministry of Industry and Commerce( MoIC) of Afghanistan, National Unity Government (NUG) has made considerable struggles to promote and increase exports[38].

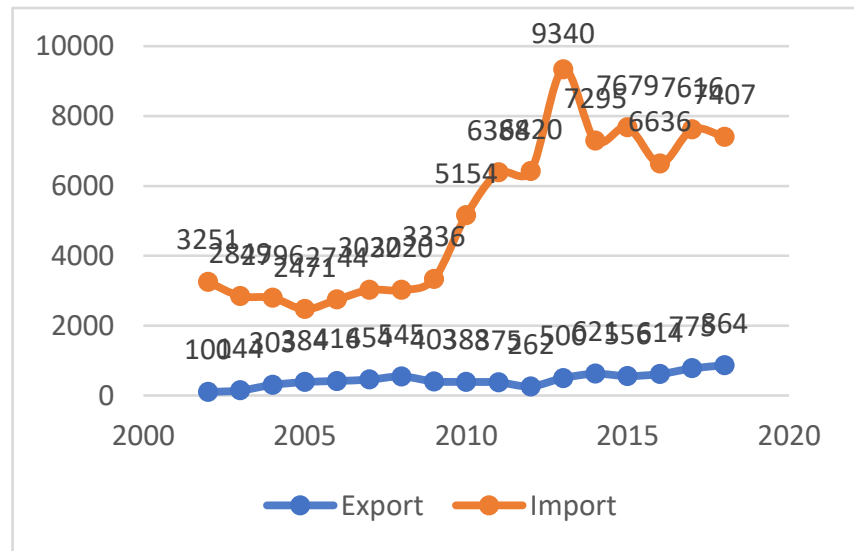

Fig.6. Imports and exports in US \$ million

Based on [12],[17],[18],[19],[20], and [38] data, the net imports were US \$3251 million in 2002 and reached to the peak of US $\$ 9340$ million in 2013. After 2013 significant declined has been noticed in imports and it reduced to US million in 2018. The data indicates that imports have (2002-2018. from US \$100 million to US \$864 million in the aforementioned period. This identifies that exports have been increased by around 40 percent on average in the last 9 years, which is a good sign for exports promotion. According to Afghan government exports promotion policy, exports targets have been set to be US \$1 billion in 2019, US \$1.5 in 2020 and US \$2 billion in 2021.

The overall situations in Afghanistan is not in the right irection. In spite of the fact that life expectancy, level of and education have increased since 2001, Afghanistan is still a poor country and highly dependent on foreign aids. Many people continue to suffer from lack of housing, health care, employment, electricity and security. High level of corruption, weak government capacity, poor public infrastructure, low level of foreign direct investment and political instability will further challenge future's economic growth in the country. Economic growth rate for the last five years is considerable lower than the average annual population growth rate of 3 percent per year. Due to lack of significant job opportunities and weak job creation, unemployment rate has been remained significantly high in reaching to the peak, it has been continuously declined to US $\$ 520.9$ in 2018. Each year enough labor supply is provided to labor market, but there is no appropriate employmen opportunities in the market.

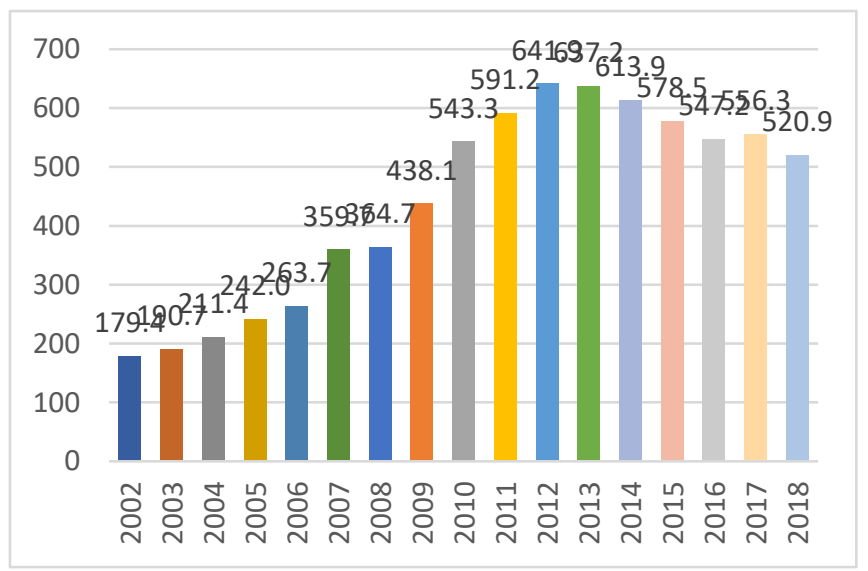

Fig.7. GDP per capita in hundred US \$

In addition, the movement in economic growth was slower than population growth rate during 2014-2018, which have had adverse effect on per capita incomes. Creating more jobs and providing quality employment opportunities for expanding workforce will increase economic growth rate. As a result, the GDP per capita will be significantly improved.

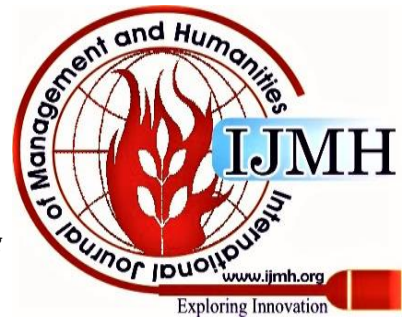




\section{CONCLUSION}

The donor-driven economy of Afghanistan hasn't been significantly developed in the last twenty years and international aids haven't been sufficiently utilized to promote economic growth in Afghanistan. If the billions dollar of aids had been optimally utilized, it would have brought positive changes in the economic development of the country. Therefore, the overall economic situations and performances of the country aren't in accordance with the expectations, and poverty and unemployment rates are constantly increasing. More than half of the ordinary national budget is financed by international community.

Majority of the population live in rural areas and work in agriculture sector where 40 percent of total workforce of the country has been employed in this sector. Improved practices and agricultural technologies haven't been in place to play an important role to increase agricultural yields in the country. The afghan government's agricultural policy hasn't played a vital role in development of agriculture sector to achieve its broad goals.

However, significant development has been noticed in banking sector and expanded in numbers to fourteen in 2019. assets size of the sector has constantly raised in the last ten years, but hasn't considerably contributed to the economic development. Besides banking sector, development in industry sector is also not fulfilling expectations, so it needs significant improvements. The sector growth rate was 1.54 percent per year during 2015-2019.

Weakand insufficient production capacity, insecurity, lack of access to new technology and finance, lack of innovation, electricity, an appropriate environment for investment, and lack of skilled workforce are the main barriers in the industry.

Afghanistan is an importing country and has experienced huge trade deficit during 2002-2018. The lowest imports were US \$3251 million in 2002 and highest US \$9340 million in 2013. On average the imports have been risen by 128 percent, while exports have been risen by only 40 percent in the aforementioned period. The lowest exports were US \$100 million in 2002 and the highest US \$864 million in 2018. Real GDP per capita was registered US \$ 179.4 in 2002, continuously increased and reached to the highest level of US \$ 641.9 in 2012, but after then regularly declined to US \$ 520.9 in 2018. Reduction in international aids, withdrawal of international forces, worsening security situations, political instability, high corruption, severe droughts, higher population growth rate than economic growth rate, weak investors' confidence and political transition were the main reasons that have had adverse effects on Afghanistan's economic growth. Due to the above mentioned reasons, the economic growth rate of the country declined from 8.8 percent in 2003 to 1.0 percent in 2018. Majority of the people continue to suffer from lack of health care, employment, housing, electricity and security. Weak government capacity, poor public infrastructure, low level of foreign direct investment, high level of corruption and political instability will further challenge future economic growth of the country. The main funding source of the sector is deposits and the

\section{ACKNOWLEDGMENT}

I would like to thank professor Dr. Yin Yingkai( my supervisor) for his timely guidance and the School of Economics at Shanghai University for providing research facilities and supports including space and technology for carrying out this research work.

\section{REFERENCES}

1. Abu Shihab, R. (2014). The Causal Relationship between Fiscal Policy and Economic Growth in Jordan. International Journal of Business and Social Science, 5(3), 203-208.

2. ADB. (2020, June 21). Economic indicators for Afghanistan. Retrieved from

https://www.adb.org/countries/afghanistan/economy

3. Akben-Selck, A. (2016). Does Firm Age Affect Profitability? Evidence from Turkey. International Journal of Economic Sciences, V(3), 1-9.

4. Akseer, T., Hayat, K., Keats, E. C., Kazimi, S. R., Maxwell-Jones, C., Shiwan, M. S., . . . Yousufzai, F. A. (2019). Afghanistan in 2019 A Survey of the Afghan People. The Asia Foundation.

5. Al-Fawwaz, T. M. (2016). The Impact of Government Expenditures on Economic Growth in Jordan (1980-2013). International Business Research, 9(1).

6. Ali, S., Ahmad, N., \& Khalid, M. (2010).The Effects of Fiscal Policy on Economic Growth : Empirical Evidences Based on Time Series Data from Pakistan. The Pakistan Development Review, 49(4), 497-512.

7. Asfaw, S. K. (2012). Poverty Reduction Effects of Agricultural Technology Adoption : A Micro-evidence from Rural Tanzania. The Journal of Development Studies , 37-41.

8. World Bank. (2008). Agriculture for Development. Washington DC: The World Bank.

9. World Bank. (2016). Afghanistan Development Update. Washington DC: The World Bank.

10. World Bank. (2017). Afghanistan Development Update. Washington DC: The World Bank.

11. World Bank. (2018). Afghanistan Development Update. Washington DC: The World Bank.

12. World Bank. (2020, June 26). GDP growth (annual \%) - Afghanistan Retrieved from www.worldbank.org: https://data.worldbank.org/indicator/NY.GDP.MKTP.KD.ZG?locatio $\mathrm{ns}=\mathrm{AF}$

13. World Bank. (2020, June 19). Unlocking the Potential of Agriculture for Afghanistan's Growth. Retrieved from www.worldbank.org: https://www.worldbank.org/en/country/afghanistan/publication/unloc king-potential-of-agriculture-for-afghanistan-growth

14. Bose, N., Haque, M. E., \& Osborn, D. R. (2007). PUBLIC EXPENDITURE AND ECONOMIC GROWTH : A DISAGGREGATED ANALYSIS FOR DEVELOPING COUNTRIES *. The Manchester School, 75(5), 533-556.

15. Catao, L. A., \& Terrones, M. E. (2005). Fiscal deficits and inflation. Journal of Monetary Economics, 52, 529-554.

16. Coad, A., Daunfeldt, S.-O., \& Halvarsson, D. (2014). Firm Age and Growth Presistence.

17. DAB. (2014). Economic and Statistical Bulletin. Kabul: Da Afghanistan Bank.

18. DAB. (2015). Economic and Statistical Bulletin . Kabul: Da Afghansitan Bank.

19. DAB. (2016). Economic and Statistical Bulletin. Kabul: Da Afghanistan Bank.

20. DAB. (2017). Economic and Statistical Bulletin. Kabul: Da Afghansitan Bank.

21. DAB. (2018). Economic and Statistical Bulletin. Kabul: Da Afghanistan Bank.

22. Easterly, W., \& Levine, R. (1997). AFRICA ' S GROWTH TRAGEDY : POLICIES AND ETHNIC DIVISIONS. The Quarterly Journal of Economics.

23. Faltermeier, L., \& Abdulai, A. (2015). The Adoption of Water Conservation and Intensification Technologies and Farm Income : A Propensity Score Analysis for Rice Farmers in Northern. researchgate.

24. Ferede, S., Ayele, G., \& Teklewold, H. (2003). Impact of Technology on Household Food Security in Tef and Wheat Farming Systems of Moretna-Jiru Wereda. EARO.

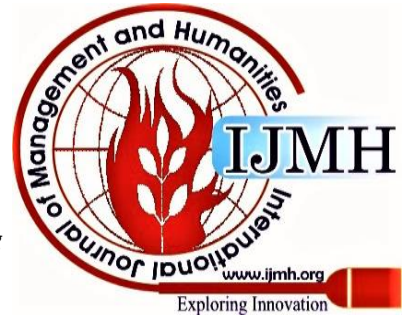




\section{Economic Development in Afghanistan}

25. Gatzweiler, F. W. (2016). Technological and Institutional Innovations for Marginalized Smallholders in Agricultural Development. Springer.

26. Ghosh Roy, A. (2012). Revisiting the Relationship between Economic Growth and Government Size. Economic Research International.

27. Goedhuys, M., \& Sleuwaegen, L. (2009). High-growth entrepreneurial firms in Africa : a quantile regression approach. Springer, 31-51.

28. Hallward-driemeier, M., \& Aterido, R. (2007). Impact of Access to Finance, Corruption and Infrastructure on Employment Growth : Putting Africa in a Global Context.

29. Heshmati, A., \& Rashidghalam, M. (2016). Labour Productivity in Kenyan Manufacturing and Service Industries. (Discussion Paper No.9923).

30. Heshmati, A., \& Su, B. (2014). Development and Sources of Labor Productivity in Chinese Provinces. China Economic Policy Review, 2(2)

31. Hossain, M. (1989). Green revolution in Bangladesh: Impact of growth and distribution of income. Dhaka University Press Ltd.

32. Hua, Y. (2016). The Relationship Between Public Expenditure on Education and Economic Growth : Evidence from China. Thesis, Clemson University.

33. Kelsey, B. (2013). Market inefficiencies and the adoption of agricultural technologies in developing countries. UC Berkeley.

34. Ketema, T. (2006). The Impact of Government Sending on Economic Growth: The Case of Ethiopia. Master Thesis, Addis Ababa University.

35. MAIL. (2019). Condensed Summary of Achievements of the Ministry of Agriculture, Irrigation, and Livestock (MAIL) during National Unity Government Term )2015-2018). Kabul: Ministry of Agriculture, Irrigation, and Livestock of Afghanistan.

36. Mendola, M. (2007). Agricultural technology adoption and poverty reduction : A propensity-score matching analysis for rural Bangladesh. ScienceDirect, 372-393.

37. Mohmand, A.-Q. (2012). The Prospects for Economic Development in Afghanistan.

38. MoIC. (2019). Exports and Imports of Afghanistan in 2015-2018. Kabul: Ministry of Industry and Commerce of Afghanistan.

39. Nguimkeu, P. E. (2013). Business Environment and Firm performance : The Case of Retailing Firms in Cameroon. Andrew Young School of Policy Studies - Georgia State University, 1-22.

40. NISA. (2019). Agricultural Prospective Report. Kabul : National Statistics and Information Authority of Afghanistan.

41. NISA. (2019). Population Estimation of Afghanistan. Kabul: National Statistics and Information Authority of Afghanistan.

42. Pain, Adma (2019).Growing out of Poverty? Questioning agricultural policy in Afghanistan, Kabul: Afghanistan Analysts Newtwork

43. Palangkaraya, A., Stierwald, A., \& Yong, J. (2009). Is Firm Productivity Related to Size and Age? The Case of Large Australian Firms. J Ind Compet Trade, 9, 167-195.

44. Rasa, R. (2017). Reasons of Kabul Bank Devaluation (Vol. 1). Khost Lemar Graphics.

45. Ravallion, M. D. (1996). How important to India's poor is the sectoral composition of economic growth? World Bank Economic Review, 10(1), 1-25.

46. Sanchez, P. A. (2009). The African Green Revolution moves forward. Springer, 37-44.

47. Sutton, J. (1997). Gibrat ' s Legacy. Journal of Economic Literature, 35(1), 40-59.

48. Worldatlas. (2020, June 15). What Are The Biggest Industries In Afghanistan? Retrieved from www.worldatlas.com: https://www.worldatlas.com/articles/what-are-the-biggest-industries-i n-afghanistan.html

49. Wu, H., Ding, S., Pandey, S., \& Tao, D. (2010). Assessing the Impact of Agricultural Technology Adoption on Farmers 'Well-being Using Propensity-Score Matching Analysis in Rural China *. Asian Economic Journal, 24(2), 141-160.

50. Zagler, M., \& Durnecker, G. (2003). Fiscal policy and economic growth. Journal of Economic Surveys, 17(3), 397-418.

\section{AUTHOR'S PROFILE}

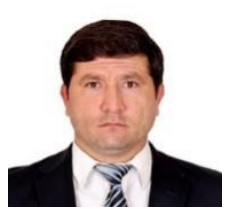

Rahmanullah Rasa, completed BBA in Business Administration from Shaikh Zayed University in 2007; bachelor upgrading and master in Management and Economics from Ruhr University Bochum, Germany in 2009 and 2013 respectively. Currently he is a $\mathrm{PhD}$ candidate at School of Economics, Shanghai University, Baoshan, China; and faculty at School of Economics at Shaikh Zayed University. He was former Director of Professional Development Center (PDC), head of Banking \& Finance Department, and head of Research Committee at School of Economics at Shaikh Zayed University. Email: Rahmanullah.rasa@szu.edu.af

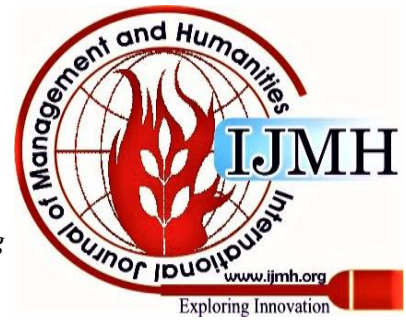

